\title{
TEACHERS' EVALUATION OF IMPORTANCE OF SELECTED DETERMINANTS OF EDUCATION OF SOCIALLY DISADVANTAGED PUPILS
}

\author{
Anna Petr Šafránková ${ }^{\bowtie}$, Klára Zátopková
}

${ }^{1 凶}$ Department of Pedagogical Sciences, Faculty of Humanities, Tomas Bata University in Zlín, Czech Republic, Mostní 5139, Zlín, 760 01, Czech Republic, +420 576037 423, safrankova@fhs.utb.cz

${ }^{2}$ Department of Pedagogical Sciences, Faculty of Humanities, Tomas Bata University in Zlín, Czech Republic

\section{Highlights}

- $\quad$ The most relevant determinants are reduced class numbers and interest of pupils in their education.

- Social environment of teachers and their religious belief and race were considered least relevant.

\section{Abstract}

Education of socially disadvantaged pupils is a current issue widely discussed, especially in the context of the philosophy of inclusive education. The present article focuses on presentation of results of a research study aimed at finding out the relevance to teachers of selected determinants involved in education of socially disadvantaged pupils. For this purpose the Q-methodology was used. We found that teachers teaching at the selected elementary schools saw as the most relevant determinants of education of socially disadvantaged pupils reduced class numbers and interest of the socially disadvantaged pupils in their own education, while determinants of the teacher's side (social environment the teacher comes from, their religious belief and race) were considered less relevant.

\section{Keywords}

Educational determinants of socially disadvantaged pupils, Q-methodology, socially disadvantaged pupils, teachers' opinions, educational support measures for socially disadvantaged pupils
Article type

Full research paper

Article history

Received: January 19, 2017

Received in revised form: March 26, 2017

Accepted: March 26, 2017

Available on-line: April 10, 2017

Petr Šafránková A. , Zátopková K. (2017) “Teachers’ Evaluation of Importance of Selected Determinants of Education of Socially Disadvantaged Pupils", Journal on Efficiency and Responsibility in Education and Science, Vol. 10, No. 1, pp. 24-33, online ISSN 1803-1617, printed ISSN 2336-2375, doi: 10.7160/eriesj.2017.100104.

\section{Introduction}

Education of socially disadvantaged pupils is a pressing issue mainly addressed in the context of inclusive education. Teachers play an important role in the education of this group of pupils (Lupton and Hempel-Jorgensen, 2012) as they are expected to mediate knowledge and skills in compliance with inherited abilities of the pupils and further develop their interests, attitudes and capabilities (Čáp and Mareš, 2007). The present study therefore focuses on presenting results of a research study focused on analysis of determinants considered relevant in relation to teacher education of socially disadvantaged pupils.

In the context of the present research on education of the given pupil group, it is important to define the notion of a socially disadvantaged pupil. In most European countries there are no accurate criteria defining socially disadvantaged pupils ${ }^{1}$. Every child is assessed individually. The priority of such assessment is not diagnostics and categorization of the pupils because this procedure is not in full compliance with the strongly asserted philosophy of inclusive education, but rather the provision of highly individual support by teachers, experts and the school (Artiles, Kozleski and Waitoller, 2011).

Generally "disadvantage" can be seen as a relative notion always defined in relation to non-disadvantaged individuals: only then it is possible to speak about "uneven conditions, approaches etc.)." The focal point of the definition of "disadvantage" is thus a certain evaluative judgement (OECD, 1998: 139). Socially disadvantaged pupils can be generally identified as individuals

1 In some countries, socially disadvantaged pupils are identified by indicators; for example England, uses FSM - free school meal (Demeuse et al., 2012). coming from an environment which renders them disadvantaged in the context of majority education. Social disadvantage can therefore be understood as a condition preventing an individual (or group) from adequate fulfilment of their potential in the sense of deprived access to certain resources or mechanisms available to other individuals. Overcoming the "disadvantage" in this context means elimination or mitigation of the given "obstacles" to access (Mayer, 2003: 2-3). When seen through the eyes of the philosophy of inclusive education, the notion of "socially disadvantaged individual" (see for example McDermott, Edgar and Scarloss, 2011) is abandoned and replaced with pupils with the need for educational support for the reason of their social disadvantage. This notion is also used in the catalogue of support measures (Felcmanová and Habrová, 2015: 8-10). According to Habrová (Felcmanová and Habrová, 2015: 8) a pupil with social disadvantage is a "category covering a wide range of causes of failure at school." These causes are not of health origin and come from outside the school, from the natural environment in which the child grows up.

The education act includes pupils with social disadvantage among pupils with special educational needs (\$16) together with pupils with physical handicap or socially excluded pupils (compare Němec and Gulová in Visser, Daniels and Cole, 2012). There is, however, a very thin boundary between social disadvantage and social exclusion. Kaleja (2014: 15) says that social exclusion in the wider sense is seen as a concept of target groups in or threatened by social exclusion, either for their significant characteristics or for their disposition. With regard to special pedagogy (Kaleja, 2015: 15) we talk about (again in the wider sense) integration and inclusion of socially 
excluded individuals or individuals with physical handicap or social disadvantage. For a better distinction, we turn to the notion of social and cultural disadvantage (Kaleja, 2015: 81). This represents the social and cultural dimension of the studied issue, where social exclusion may be considered as the social dimension and the educative dimension; in other words: "The context of social disadvantage is mainly linked to the social dimension with regard to the educational process."

For the purpose of the present study, we consider a socially disadvantaged pupil as being a child coming from a family environment who, due to his or her social and economic conditions inadequately motivates or provides insufficient or no background for development of mental, volitive and emotional properties of the child (Šafránková and Kocourková, 2013; Petr Šafránková and Hrbáčková, 2016a).

The main aim of the paper is to find out how teachers assess selected determinants affecting education of socially disadvantaged pupils. The paper is divided into three main sections - theoretical background of education of socially disadvantaged pupils; description of the research and results of the research; discussion. Within theoretical background the paper presents definition of the group of socially disadvantaged pupils in the context of Czech educational environment and specifics of education socially disadvantaged pupils through support measures for reduction of social disadvantage pupils. The second part of the paper presents the main findings of the research using Q-methodology. The paper includes also discussion about the results and conclusion.

\section{Education of socially disadvantaged pupils in the context of inclusion}

Education is generally understood as a major means of social mobility - facilitating employment, economic freedom and stability, and contributing to an improved quality of life for those who experience its opportunities (Drake et al. 2015: 1). In this context, in both Czech and international educational environment, the role of school education in relation to pupils coming from socially disadvantaged environment is often emphasized. This discourse is currently seen in the light of the concept of equal educational opportunity ${ }^{2}$. This fact is also documented by the National programme of development of education in the Czech Republic (the "White Book") (Kotásek, 2001). Likewise, this issue is grasped by the Strategy of educational policy of the Czech Republic by 2020 (Ministry of Education, Youth and Sport of CR, 2014), with one of the key themes being elimination of inequality in education. The strategy focuses on formal equality of approach to education and also accents the ability of the educational system to create conditions

$2 \quad$ Greger (2010: 22) says that this concept moved to the foreground of Czech educational policy in the 1990s. The concept of equal opportunities in education is often mentioned together with the concept of equity in education as a certain starting point. Greger (2006; 2010) says that on the way towards equity in the context of education, one can come across two concepts, the equality of access and the equality of treatment, which are close to the meritocratic approach, as they accept inequalities existing despite compliance with equality of conditions (in the school environment this may include the number and quality of textbooks, class size, methods and forms of teaching used etc.) and comparability of treatment (i.e. regardless the social environment the pupil comes from). In addition to the above mentioned concepts Greger (2010) also speak about equality of achievement, where he appeals to the educational system to provide to every pupil a certain functional minimum. (compare also EGREES, 2005). and to apply effective procedures for effective compensation of health, social, cultural and other personal disadvantages for determination of the inequality in the achieved results by factors which cannot be affected by the individual to be minimised so that all pupils are able to achieve at least the basic level of the needed knowledge and skills (Ministry of Education, Youth and Sport of CR, 2016: 13; compare also Greger, 2010).

This is the context of stepwise development of the concept of inclusive education ${ }^{3}$, which may be understood as a certain philosophy, principle or even practice based on human rights and social justice (Rombo, 2006). The numerous studies on this theme have not arrived at a unified definition of inclusion (Booth, 1996; Booth and Ainscow, 1998; Dyson and Millward, 2000). Generally speaking, inclusive education provides equal status to all pupils regardless their personality specifics or specifics of the environment the child comes from. In this sense emphasis is mainly laid on provision of respecting approach, accentuation of human dignity, independence and "fairness". Inclusive education is based on the art of reaction to and work with diversity of the pupils (Ainscow and Dyson, 2006). Ainscow and Dyson (2006: 15) defined six concepts of inclusion: 1) inclusion as an interest in handicapped pupils and pupils with special learning needs; 2) inclusion as a response to exclusion; 3) inclusion in relation to all groups threatened by exclusion; 4) inclusion as development of schools for all; 5) inclusion as education for all; and 6) inclusion as an approach to education and the society.

The scales of strategies used by the schools for management of pupil diversity may be different. To assure inclusive education, the Czech educational system allows pupils from socially disadvantaged family environments to make use of various support measures (compare Ministry of Education, Youth and Sport of CR $2016 \S 16$ ). Education of socially disadvantaged pupils should above all be based on appropriate lesson organisation, conditions (personal, material and content) and relevant strategies (Filová, Havel and Kratochvílová in Němec, Vojtková, 2009: 50). Personal conditions of education of socially disadvantaged pupils is one of the key determinants of effective education of this specific group of pupils. Generally speaking, education of socially disadvantaged pupils is demanding for the teacher not only from the professional point of view but also from the pedagogical, psychological and personality perspectives as well as social qualities and competences. Personal conditions of education of socially disadvantaged pupils must be understood not only from the viewpoint of the teacher but also through the eyes of other pedagogical professionals ${ }^{5}$. Not less relevant is assistance of other involved experts (i.e. cooperation with school psychologists and advisers, special pedagogy centres and methodologists of prevention, educational advisers,

3 This concept is perceived as an integral part of a wider discourse on social including as a reaction to processes of differentiation in the society (compare Mareš and Sirovátka, 2008).

4 The notion of fairness is defined by Rawls (1971) in the context of specification of the theory of justice. Justice in this context corresponds to the original status of equality (as a purely hypothetical status), the status of nature in the traditional theory of social contract, in the context of which, under the condition of symmetrical relations, mutual consensus may be reached.

$5 \quad$ What mainly needs to be emphasized is the role of assistant teachers and other pedagogues for inclusive education is only possible if all actors of the educational environment respect and accept the philosophy of inclusive education (compare also Booth and Ainscow, 2002). 
special teachers and social workers, physicians, etopedics etc.). Material conditions of education of socially disadvantaged pupils include, for example, appropriate teaching aids (Filová, Havel and Kratochvílová in Němec and Vojtková, 2009: 53). These aspects of education of socially disadvantaged pupils may be very strong especially where the social disadvantage of the pupil is given by economic situation of the family.

And last but not least, there are the curriculum content conditions of education of this specific group of pupils. Every pupil, regardless of his or her individual characteristics and capabilities, should feel welcomed at school, respected and this is where the content and process aspects should lead education of socially disadvantaged pupils (Filová, Havel and Kratochvílová in Němec and Vojtková, 2009: 51).

\section{Support measures for reduction of social disadvantage of pupils}

In the context of the above one can say that individual educational policies address the issue of justice in education of socially disadvantaged pupils differently (see for example Demeuse et al., 2012). At present inclusive education is accentuated in many countries as a way towards inclusive society (compare Kasíková and Straková, 2011). In the Czech education environment this issue is currently widely discussed in the context of the novella of the education act (Act no. 561/2004 Coll.), where the support measures are defined as: 1) Advisory service of the school and educational advisory offices; 2) adjustment of organisation, content, evaluation, forms and methods of education and school services; 3 ) modification of conditions of admission to education and education completion; 4) use of compensation aids, special textbooks and special teaching aids, etc.; 5) adoption of the expected outcomes of education within the limits defined by the framework educational programmes and accredited educational programmes; 6) education according to individual learning plans; 7) use of teacher assistants; 7) use of another pedagogue, interpreter from/into Czech sign language etc.; and 8) provision of education and school services in adapted buildings equipped with special technology, etc. These measures focus on the whole class of pupils with special learning needs, so not all of the above measures may need to be used for/by socially disadvantaged pupils. A more detailed account on the support measures is given by Michalík, Baslerová and Felcmanová (2015), who on the basis of empirical studies, offers the following classification of the support measures: 1) teaching organisation; 2) modification of teaching methods and forms; 3) intervention; 4) aids; 5) content adjustment; 6) evaluation; 7) class preparation; 8) social and health support; 9) work with the class; and 10) environment adaptation. The above mentioned authors speak in terms of clusters associating individual elements of social, pedagogical, psychological and social support. The individual areas overlap and are linked to each other.

The research study described below is based on the above support measures, extended with Bronfenbrenner's (1979) ecological model and factors of teacher specifics (see also personal conditions of education of socially disadvantaged pupils as mentioned above) and pupil specifics, which may also influence education of socially disadvantaged pupils (see also for example Buehl and Beck, 2015).

\section{Materials and Methods}

The present study summarises the main findings of the research which was aimed at finding out how teachers assess selected determinants affecting education of socially disadvantaged pupils, or at identification of determinants teachers find most relevant and vice versa, which they see as the least significant in the context of education of socially disadvantaged pupils.

The research population consisted of 99 respondents ( 21 male and 78 female) from selected regions of the Czech Republic ${ }^{6}$, of which 37 respondents were from the Ústecký region, 39 respondents from the Liberecký region and 23 respondents from the Pardubický region. The basic research population was intentionally selected and the selection was based on availability. The internet questionnaire was sent to email addresses of schools available in the directory of the Ministry and school establishments owned and paid by the Ministry of Education, Youth and Sport of CR (Ministry of Education, Youth and Sport of CR, 2016). All headmasters of the selected schools were sent a request to fill the questionnaire out. They were at the same time asked to send the link to all teachers working in the school in the given period of the school year. Where contacts to individual teachers were available on the web of the school, these teachers were addressed individually. In total, 422 teachers were addressed and 99 questionnaires were returned.

Due to the large number of determinants of education of socially disadvantaged pupils Q-methodology was chosen as the research tool. This method allowed the determination of how the respondents assessed a certain quantity of objects, which was large (Chráska, 2007: 231; Brown, 1996). As mentioned by Coogan and Herrington (2011: 24), Q-study specifically studies correlations between personal opinions, not testing the respondents themselves. Its big advantage also is the possibility to examine small groups of persons (Chráska, 2007: 236); i.e., the method does not require large numbers of respondents. The respondents were asked to decide what was relevant or important from their point of view. That allowed by Q-methodology (Coogan and Herrington, 2011: 24). According to Chráska (2007: 231) Q-types are sorted by various criteria (such as relevance, significance, influence etc.), representing the objects to be evaluated (such as statements, opinions, values, or determinants). This is mostly based on the so called quasinormal distribution (Chráska, 2007: 231). On this basis the Q types are divided into eleven groups with maximum numbers of allocated Q types defined. For the purpose of our research, the Q classification can be depicted as follows:

6 The region selection was intentional with regard to expected maximum concentrations of socially disadvantaged pupils; i.e. the selection was based on socio-demographic analysis (SocioFactor s.r.o., 2013: 429). Socio-demographic analysis specified the level of threat to children with regard to three dimensions: demographic and social environment, economic activity, unemployment and allowance grant and incompleteness or impaired function of the family or the risk of one. Three regions were selected on the basis of these dimensions: Ústecký region (a high level of threat to children and youth), Liberecký region (mean level of threat to children and youth), Pardubický region (low level of threat to children and youth). The research population intentionally excluded church schools, special, alternative and international schools, as the aim was to grasp specifics of standard elementary schools. 


\begin{tabular}{|c|c|c|c|c|c|c|c|c|c|c|c|c|}
\hline \multicolumn{13}{|c|}{ Permitted number of Q types } \\
\hline \multirow{3}{*}{$\begin{array}{l}\text { Most } \\
\text { relevant }\end{array}$} & 2 & 3 & 4 & 7 & 9 & 10 & 9 & 7 & 4 & 3 & 2 & \multirow{3}{*}{$\begin{array}{l}\text { Least } \\
\text { relevant }\end{array}$} \\
\hline & & & & & & & & & & & & \\
\hline & 1 & 2 & 3 & 4 & 5 & 6 & 7 & 8 & 9 & 10 & 11 & \\
\hline \multicolumn{13}{|c|}{ Scoring } \\
\hline
\end{tabular}

Table 1: Quasi-normal distribution of $Q$ classification of determinants of education of socially disadvantaged pupils (source: Chráska, 2007: 231)

The respondents were submitted in total 60 determinants (Q-types) thought possibly to affect their pedagogical activity in contact with socially disadvantaged pupils. These Q types were based on analysis of the catalogue of support measures to pupils in need of support for the reason of social disadvantage (Felcmanová and Habrová, 2015). Further basic assumption was represented by the Framework Educational Plan and other strategic documents. The categories based on the catalogue of support measures (Felcmanová and Habrová, 2015) were extended by the determinants coming from the same document.

These Q-types were submitted to the respondents in the order from Q-1 to Q-60 without categorisation. The reason was that we assumed potential effect of these categories on allocation of the level of relevance to the individual determinants.

The basic analysis of the relevance allocated to the individual determinants was performed by means of descriptive statistics in the program Statistica version 10. This statistical method allows us to find the mean value of the relevance allocated to each determinant (Q-type) and also standard deviation for each Q-type. Analysis of these values may create the basic hierarchy of relevance of the individual determinants by the same principle as the Q-methodology itself (i.e. from the most to the least relevant).

\section{Results}

The research population included in total 99 respondents, of which 78 were females (a little less than $79 \%$ ) and 18 males (circa 21\%). Analysis of the open questions found that the lowest age of the respondents was 24 and the highest was 67 years. This means a large age span of the respondents. For better interpretation, we divided the respondents into four age categories based on the basic age categories of Machová (2008: 179). The first category included respondents $24-30$ years old, in total 15 respondents (about 15\% of the total number). The group of respondents between 31 and 45 years of age was much larger (38 respondents, 38.38\%). The largest group was however represented by respondents between 46 and 60 years of age, including 44 respondents (44.4\%). Only one respondent was older than 61 years. This respondent was in particular 67 years old. One of the respondents did not give his/her age in the open question section but his/her answers are included in the research analysis.

Another item of basic information about the respondents was the length of their teaching practice. Three respondents reported the length of teaching practice shorter than 1 year. The same number of respondents reported $1-2$ years of teaching practice. Six more respondents based their opinions on $3-5$ years of teaching practice. The numbers of respondents in these three categories correspond to the above mentioned age categories, i.e., 15 respondents with 0 - 5 years of practical experience and 15 respondents of the age category $24-30$ years. The same conclusion cannot be drawn for the other categories by length of teaching practice, though, where the numbers of respondents differ significantly from the numbers in the respective age categories. In total 15 respondents defined the length of their teaching practice by the period from 6 to 10 years $(15 \%)$, while 12 respondents worked as teachers for 11 15 years (in total $12.1 \%$ ) and 17 respondents reported practical experience in school between 16 and 20 years long (17.2\%). The largest category with regard to years of teaching practice was represented by " 21 years or more" with the total number of 40 respondents (more than $40 \%$ ).

Another (and the last) informative question attempted to determine previous experience in teaching socially disadvantaged pupils. In total 82 respondents (83\%) reported some experience in teaching this group of pupils and only a mere 17 respondents $(17 \%)$ had no experience at all in this area.

The other part of the research already focused on allocated relevance of the individual determinants of education of socially disadvantaged pupils using Q-methodology tool. On the basis of analysis of this Q-classification, as described above, we compiled a table showing the individual determinants (Q-types) in order from the most to the least relevant. The order was determined by calculation of the mean value of relevance reached by each determinant and standard deviation. The Table 1 shows the order of the individual Q-types according to relevance ascribed to them by the respondents on the basis of calculated means and standard deviations. The number of category shows the category type the determinant belongs to. The categories were defined on the basis of the catalogue of support measures for education of pupils with social disadvantage (Felcmanová and Habrová, 2015). The following clue is to serve for better understanding of the issue:

- Category 1 -Adjustment of teaching mode

- Category 2 - Modification of teaching forms and methods

- Category 3 - Intervention

- Category 4 - Class preparation

- Category 5 - Class work

- Category 6-Adjustment of environment

- Category 7 - Health and social support

- Category 8 - Determinants on teacher side

- Category 9 - Determinants on pupil side 


\begin{tabular}{|c|c|c|c|c|c|}
\hline Order & $\begin{array}{l}\text { Q-type } \\
\text { number }\end{array}$ & $\begin{array}{l}\text { Category } \\
\text { number }\end{array}$ & Q-type name & Mean & SD \\
\hline 1 & Q-5 & 6 & $\begin{array}{l}\text { Reduction of the number of pupils in } \\
\text { class }\end{array}$ & 3.929 & 2.749 \\
\hline 2 & Q-38 & 9 & Pupil's interest in being educated & 4.576 & 2.556 \\
\hline 3 & Q-18 & 8 & $\begin{array}{l}\begin{array}{l}\text { Empathy and understanding on } \\
\text { teacher's side }\end{array} \\
\end{array}$ & 4.697 & 2.072 \\
\hline 4 & Q-13 & 3 & $\begin{array}{|lcc|}\begin{array}{l}\text { Individual work } \\
\text { disadvantaged pupil }\end{array} & \text { with } & \text { socially } \\
\end{array}$ & 4.768 & 2.320 \\
\hline 5 & Q-21 & 8 & \begin{tabular}{|llll}
$\begin{array}{l}\text { Teacher's respect } \\
\text { individuality }\end{array}$ & for & pupil \\
\end{tabular} & 4.889 & 2.394 \\
\hline 6 & Q-20 & 8 & Teacher's communication skills & 4.939 & 1.873 \\
\hline 7 & Q-25 & 8 & $\begin{array}{l}\text { Teacher's ability to raise interest of the } \\
\text { pupils in learning }\end{array}$ & 4.960 & 1.895 \\
\hline 8 & Q-39 & 2 & $\begin{array}{l}\text { Motivation of socially disadvantaged } \\
\text { pupil }\end{array}$ & 4.990 & 2.087 \\
\hline 9 & Q-33 & 8 & $\begin{array}{l}\text { Teacher's consistent insistance on } \\
\text { educational requirements }\end{array}$ & 5.061 & 1.806 \\
\hline 10 & Q-16 & 5 & \begin{tabular}{|l|} 
Class order and atmosphere \\
\end{tabular} & 5.131 & 2.234 \\
\hline 11 & Q-47 & 3 & $\begin{array}{l}\text { Mutual trust between the teacher and } \\
\text { the socially disadvantaged pupil }\end{array}$ & 5.162 & 2.049 \\
\hline 12 & Q-48 & 3 & $\begin{array}{l}\text { Mutual trust between the teacher } \\
\text { and the family of the socially } \\
\text { disadvantaged pupil }\end{array}$ & 5.253 & 1.940 \\
\hline 13 & Q-35 & 5 & $\begin{array}{l}\text { Bringing pupils up to mutual tolerance } \\
\text { and respect }\end{array}$ & 5.283 & 1.874 \\
\hline 14 & Q-8 & 7 & Presence of teacher's assistant & 5.333 & 2.896 \\
\hline $15-16$ & Q-28 & 8 & $\begin{array}{l}\text { Tolerance of the teacher (in relation } \\
\text { to diverse cultures and social } \\
\text { environments of the pupils) }\end{array}$ & 5.414 & 2.080 \\
\hline $15-16$ & Q-31 & 8 & $\begin{array}{l}\text { Teacher's belief in purposefulness of } \\
\text { their efforts }\end{array}$ & 5.414 & 2.055 \\
\hline 17 & Q-37 & 4 & $\begin{array}{l}\text { Ability of the teacher to clearly and } \\
\text { comprehensibly formulate instructions }\end{array}$ & 5.434 & 1.814 \\
\hline 18 & Q-40 & 2 & $\begin{array}{l}\text { Experience of success of socially } \\
\text { disadvantaged pupil }\end{array}$ & 5.444 & 1.847 \\
\hline 19 & Q-46 & 3 & $\begin{array}{l}\text { Intense and effective cooperation } \\
\text { with the family of the socially } \\
\text { disadvantaged pupil }\end{array}$ & 5.475 & 1.976 \\
\hline 20 & Q-3 & 4 & $\begin{array}{l}\text { More extensive teacher preparation for } \\
\text { lessons }\end{array}$ & 5.485 & 2.727 \\
\hline $21-22$ & Q-23 & 8 & $\begin{array}{l}\text { Individual approach of the teacher to } \\
\text { socially disadvantaged pupils }\end{array}$ & 5.515 & 2.087 \\
\hline $21-22$ & $\mathrm{Q}-22$ & 8 & Teacher's education and qualifications & 5.515 & 2.388 \\
\hline 23 & Q-36 & 5 & $\begin{array}{l}\text { Ability of the teacher to support equal } \\
\text { position of all children in class }\end{array}$ & 5.531 & 1.700 \\
\hline $24-25$ & Q-54 & 5 & Positive school atmosphere & 5.606 & 1.926 \\
\hline $24-25$ & Q-34 & 8 & $\begin{array}{l}\text { Respect for individuality of socially } \\
\text { disadvantaged pupils }\end{array}$ & 5.606 & 2.089 \\
\hline 26 & Q-49 & 3 & $\begin{array}{l}\text { Definition of clear rules of } \\
\text { communication of the school with } \\
\text { parents of socially disadvantaged } \\
\text { pupils }\end{array}$ & 5.626 & 2.107 \\
\hline $27-28$ & Q-41 & 9 & \begin{tabular}{|l}
$\begin{array}{l}\text { Personality features of socially } \\
\text { disadvantaged pupil }\end{array}$ \\
\end{tabular} & 5.667 & 1.938 \\
\hline $27-28$ & Q-19 & 8 & $\begin{array}{l}\text { Teacher's experience in education of } \\
\text { socially disadvantaged pupils }\end{array}$ & 5.667 & 2.079 \\
\hline 29 & Q-26 & 8 & $\begin{array}{l}\text { Social empathy of teacher in relation } \\
\text { to socially disadvantaged pupils }\end{array}$ & 5.687 & 2.423 \\
\hline 30 & Q-1 & 2 & Modification of teaching methods & 5.727 & 2.691 \\
\hline 31 & Q-42 & 5 & Intensive work with class & 5.788 & 2.130 \\
\hline 32 & Q-32 & 8 & Teachers's resistance to stress & 5.808 & 2.132 \\
\hline 33 & Q-44 & 9 & Pupil's healthy self-esteem & 5.970 & 1.746 \\
\hline 34 & Q-15 & 2 & $\begin{array}{|lc|}\begin{array}{l}\text { Group work } \\
\text { communication }\end{array} & \text { supporting } \\
\end{array}$ & 5.980 & 2.157 \\
\hline 35 & $\mathrm{Q}-2$ & 2 & Modification of educational content & 6.000 & 3.010 \\
\hline 36 & Q-43 & 9 & $\begin{array}{l}\text { The pupil's belief in being able to } \\
\text { affect the situation he/she is in }\end{array}$ & 6.091 & 1.901 \\
\hline 37 & Q-56 & 5 & $\begin{array}{l}\text { System of clear sanctions if the defined } \\
\text { rules are not complied with }\end{array}$ & 6.101 & 2.252 \\
\hline 38 & Q-52 & 7 & $\begin{array}{l}\text { Support by headmaster and peers } \\
\text { (positive work environment, positive } \\
\text { team atmosphere) }\end{array}$ & 6.152 & 1.740 \\
\hline 39 & Q-17 & 8 & $\begin{array}{l}\text { Teacher's authenticity in behaviour } \\
\text { towards the pupil }\end{array}$ & 6.192 & 2.184 \\
\hline 40 & Q-11 & 1 & $\begin{array}{l}\text { Selection of a suitable workplace for } \\
\text { the pupil, modification of the class } \\
\text { seating order }\end{array}$ & 6.202 & 2.478 \\
\hline
\end{tabular}

\begin{tabular}{|c|c|c|l|c|c|}
\hline 41 & Q-27 & 8 & $\begin{array}{l}\text { Teacher's authenticity in behaviour } \\
\text { towards the parents of the socially } \\
\text { disadvantaged pupil }\end{array}$ & 6.232 & 2.064 \\
\hline 42 & Q-7 & 3 & $\begin{array}{l}\text { Individual learning plan for socially } \\
\text { disadvantaged pupil }\end{array}$ & 6.323 & 2.502 \\
\hline 43 & Q-12 & 2 & $\begin{array}{l}\text { Targeted creation of space/ } \\
\text { opportunities for self-fulfilment of } \\
\text { socially disadvantaged pupils }\end{array}$ & 6.404 & 1.958 \\
\hline $44-45$ & Q-45 & 9 & $\begin{array}{l}\text { Relationship of socially disadvantaged } \\
\text { pupils to self-education }\end{array}$ & 6.475 & 1.837 \\
\hline $44-45$ & Q-57 & 7 & $\begin{array}{l}\text { Cooperation with the committee for } \\
\text { social and legal protection of children }\end{array}$ & 6.475 & 2.106 \\
\hline 46 & Q-14 & 2 & Cooperative learning & 6.495 & 2.192 \\
\hline $47-48$ & Q-59 & 7 & $\begin{array}{l}\text { Presence of special pedagogue in the } \\
\text { school }\end{array}$ & 6.576 & 2.429 \\
\hline $47-48$ & Q-58 & 7 & $\begin{array}{l}\text { Cooperation with psychological } \\
\text { advisory office for schools }\end{array}$ & 6.576 & 2.214 \\
\hline 49 & Q-55 & 5 & $\begin{array}{l}\text { Existence of behavioural models } \\
\text { appropriate for imitation by the pupils } \\
\text { (teachers, peers }\end{array}$ & 6.616 & 1.872 \\
\hline 50 & Q-29 & 8 & Teacher's mental competence & 6.737 & 2.197 \\
\hline 51 & Q-60 & 7 & $\begin{array}{l}\text { Presence of school psychologist in the } \\
\text { school }\end{array}$ & 6.899 & 2.211 \\
\hline 52 & Q-9 & 1 & Timetable adaptation & 7.192 & 0.253 \\
\hline 53 & Q-53 & 2 & Unified school philosophy & 7.212 & 1.991 \\
\hline 54 & Q-6 & 1 & Inner differentiation of pupils at school & 7.343 & 2.200 \\
\hline 55 & Q-51 & 6 & $\begin{array}{l}\text { Material equipment of the classroom/ } \\
\text { school }\end{array}$ & 7.364 & 2.252 \\
\hline 56 & Q-4 & 6 & Environmental adjustment & 7.485 & 2.401 \\
\hline 57 & Q-50 & 7 & Level of school inclusiveness & 7.667 & 2.157 \\
\hline 58 & Q-10 & 6 & $\begin{array}{l}\text { Alternative spatial arrangement in } \\
\text { classroom }\end{array}$ & 7.899 & 2.197 \\
\hline 59 & Q-24 & 8 & Social origin of the teacher & 8.323 & 2.641 \\
\hline 60 & Q-30 & 8 & Teacher's religious belief and race & 9.303 & 2.341 \\
\hline & $2:$ & & determinants of education & $0 f$ \\
\hline
\end{tabular}

Table 2: Order of determinants of education of socially disadvantaged pupils (source: own calculation)

The mean value by every determinant tells about the relevance the respondents ascribed to it. The higher the mean value, the lower the relevance of the determinant for the teacher.

On the basis of the calculated mean (M), standard deviation (SD) and principle of $\mathrm{Q}$ classification determinants considered most relevant by the respondents in teaching socially disadvantaged pupils may be determined. The most relevant Q-types are those with the lowest means, i.e. reduction of the number of pupils in class $(\mathrm{M}=3.929 ; \mathrm{SD}=2.749)$ and interest of the pupil in his/her own education ( $\mathrm{M}=4.576 ; \mathrm{SD}=2.556)$. The following three Q-types may be considered very important and the teachers should apply them in their work not only with socially disadvantaged pupils (two of the Q-types directly fall within the category of teacher-side determinants). Respondents ascribed this level of relevance to empathy and understanding on the part of the teacher $(\mathrm{M}=4.697 ; \mathrm{SD}=2.072)$, individual work with socially disadvantaged pupil $(\mathrm{M}=4.768 ; \mathrm{SD}=2.320)$ and teacher's respect for pupil individuality $(\mathrm{M}=4.889 ; \mathrm{SD}=2.394)$.

Important determinants of education of socially disadvantaged pupils according to the respondents include communication skills of the teacher $(\mathrm{M}=4.939 ; \mathrm{SD}=1.873)$, ability of the teacher to raise the interest of pupils in class work $(\mathrm{M}=4.960$; $\mathrm{SD}=1.895)$, motivation of socially disadvantaged pupils $(\mathrm{M}=4.990 ; \mathrm{SD}=2.087)$ and systematic insistence of the teacher on educational requirements $(\mathrm{M}=5.061 ; \mathrm{SD}=1.806)$. These four determinants too are based on the teacher's skills and are included in the teacher-side determinants together with the category of modification of teaching methods and forms. We assume that the evaluation of the determinant defined as the ability of the teacher to raise the interest and motivation of socially disadvantaged pupils reflects the most relevant determinant: the pupils' interest in education. We believe that to maintain interest and motivation 
of a large number of pupils in class is not always possible, which returns us back to the high relevance of the number of pupils in class.

The performed analysis further shows as relevant determinants the order in class and the class atmosphere $(\mathrm{M}=5.131 \mathrm{SD}=2.34)$, together with mutual trust between the teacher and the socially disadvantaged pupil $(\mathrm{M}=5.162 ; \mathrm{SD}=2.049)$ and between the teacher and the family of the socially disadvantaged pupil $(\mathrm{M}=5.253$; $\mathrm{SD}=1.940)$. Another important determinant is leading pupils to mutual tolerance and respect $(M=5.283$; $\mathrm{SD}=1.874$ ), which may be connected with the above mentioned class order and atmosphere in class. It may be assumed that if all (pupils and teachers) in class tolerate each other, the class climate will be more pleasant, which might positively affect work with the socially disadvantaged pupils. This is probably also why the respondents considered relevant tolerance of the teacher in relation to different cultures and social environments the pupils come from $(\mathrm{M}=5.414 ; \mathrm{SD}=2.080)$ and belief of the teacher in purposefulness of what he/she does $(\mathrm{M}=5.414$; $\mathrm{SD}=2.055)$. In the area of intervention, the relevant determinants included presence of teacher's assistant $(\mathrm{M}=5.333 ; \mathrm{SD}=2.896)$, but presence of other experts (teacher with special qualifications or school psychologist) was not considered very relevant. This may be because the teacher's assistant works with the pupil with special learning needs, including social disadvantage, individually.

A relatively relevant part of what affects teachers teaching socially disadvantaged pupils is represented by the category "teachers' preparation for class" with the two related determinants - the ability of the teacher to formulate clear and comprehensible instructions $(\mathrm{M}=5.434 ; \mathrm{SD}=1.814)$ and more extensive teacher preparation for class work $(\mathrm{M}=5.485$; $\mathrm{SD}=2.727)$. This is also connected with the experienced success of the socially disadvantaged pupil at school $(\mathrm{M}=5.444$; $\mathrm{SD}=1.847$ ), which is an important motivator in education of these pupils, together with intense and effective cooperation with the family of the socially disadvantaged pupil $(\mathrm{M}=5.475$; $\mathrm{SD}=1.976$ ). However, the latter is considered less relevant than the very mutual trust between the teacher and the socially disadvantaged pupil. Relatively interesting was the finding concerning individual approach of the teacher to socially disadvantaged pupils $(\mathrm{M}=5.515 ; \mathrm{SD}=2.087)$ as a determinant considered rather relevant, while individual work with the pupil was considered very relevant. Also the ability of the teacher to support equal positions of all children in class was considered rather relevant $(\mathrm{M}=5.531 ; \mathrm{SD}=1.700)$, while at the same time it was important for the respondents to respect individuality of socially disadvantaged pupils $(M=5.606 ; \mathrm{SD}=2.089)$. Another interesting fact is that the respondents considered rather relevant the teachers' education and qualifications $(\mathrm{M}=5.515 ; \mathrm{SD}=2.388)$ unlike other competences (communication skills, ability to raise interest in pupils, empathy and understanding, etc.), perceived by the respondents as more relevant. Also the school atmosphere was only considered rather relevant $(M=5.606 ; S D=1.926)$, thus being seen as less relevant than order and atmosphere in the classroom. This finding is more logical considering the fact that work with socially disadvantaged pupil is situated in the classroom rather then generally in the school (in lessons, during breaks etc.).

The principle of Q-classification leads to the median values of relevance of the individual Q-types. These determinants cannot be straightforwardly defined as relevant or irrelevant but on the basis of their mean value, or standard deviation, they may be classified as rather relevant or rather irrelevant. Taking this approach, we can evaluate definition of clear rules of communication of the school with the family of the socially disadvantaged pupil $(\mathrm{M}=5.626 ; \mathrm{SD}=2.107)$ still as rather relevant. This may be considered logical with regard to the relevance of mutual trust between the teacher and the family and intense and effective cooperation with the family of the socially disadvantaged pupil (with regard to the relevance of complementary nature of these two institutes in relation to education of socially disadvantaged pupils). Considering the importance of individual work with a socially disadvantaged pupil, personality features of the socially disadvantaged pupil may then be seen as rather relevant $(M=5.667$; $S D=1.938)$ together with experience of the teacher with education of socially disadvantaged pupils $(M=5.667 ; \mathrm{SD}=2.079)$. This may also be related to the social empathy of the teacher in relation to socially disadvantaged pupils $(\mathrm{M}=5.687 ; \mathrm{SD}=2.423)$ and the potential need for modification of teaching methods $(M=5.727$; $\mathrm{SD}=2.691)$. Overall, the adaptation of the educational content is then seen by the respondents as rather irrelevant $(M=6.000$; $\mathrm{SD}=3.010)$ : for example, intense work with the class $(\mathrm{M}=5.788$; $\mathrm{SD}=2.130$ ). It may be said then that individual work is much more relevant than work with the class as a whole, but in the class atmosphere the pupils must be brought up to mutual respect and tolerance. This is not consistent with evaluation of group work supporting communication $(\mathrm{M}=5.980 ; \mathrm{SD}=2.157)$, which may be perceived as rather irrelevant. The same definition of relevance applies to healthy self-esteem of the pupil $(M=5.970$; $\mathrm{SD}=1.746)$ and the teacher's resistance to stress $(\mathrm{M}=5.808$; $\mathrm{SD}=2.132$ ).

An individual learning plan for socially disadvantaged pupil was considered rather irrelevant by the respondents $(M=6.323$; $\mathrm{SD}=2.502$ ). It may therefore be assumed that teachers consider individual work important: for example, with help of teacher's assistants, without the need for individual learning plan for the pupil. Likewise, the need for a special work place for the socially disadvantaged pupil is considered rather irrelevant, including the overall arrangement of the class seating plan $(M=6.202$; $\mathrm{SD}=2.478$ ) and targeted creation of space for self-fulfilment of socially disadvantaged pupils ( $M=6.404 ; \mathrm{SD}=1.958)$. It is possible to think that this perceived relevance, or rather irrelevance, is affected by the above mentioned ability of the teacher to support equal positions of all pupils, which is seen as rather relevant. We assume that the seating arrangement in class and the targeted creation of space for the socially disadvantaged pupils might disturb the equal positions of all pupils in class, at least in the eyes of the pupils themselves. Further rather irrelevant determinants following from the analysis include belief of the pupil in his/her ability to influence the situation in which he/she finds himself/herself in $(\mathrm{M}=6.091 ; \mathrm{SD}=1.901)$ and educational aspirations of socially disadvantaged pupils $(\mathrm{M}=6.475 ; \mathrm{SD}=1.837)$. Rather irrelevant was also the system of clear sanctions for non-compliance with the preset rules $(\mathrm{M}=6.101 ; \mathrm{SD}=2.252)$. We assume that perceived relevance of this determinant is affected by the high relevance of mutual trust between the teacher and the pupil as well as between the teacher and the family of the pupil. One may expect that in the case of establishment of mutual trust, the system of clear sanctions is no longer needed. This determinant may also be affected by the preset rules of communication between the school and the parents. This is also assessed still as rather 
relevant and we believe that when these rules are observed, the system of sanctions is irrelevant. Rather irrelevant was also support on the part of the headmaster and the peers (good work environment team of teachers in school) $(\mathrm{M}=6.152 ; \mathrm{SD}=1.740)$. Further rather irrelevant determinants included authenticity of the teacher in relation to the pupil $(\mathrm{M}=6.192 ; \mathrm{SD}=2.184)$ and in relation to the teachers of the socially disadvantaged pupil $(\mathrm{M}=6.232 ; \mathrm{SD}=2.064)$.

The boundary between the rather irrelevant and least relevant is represented by two determinants with the same mean value - educational aspirations of socially disadvantaged pupils and cooperation with the committee of social and legal protection of children. On the basis of the standard deviation calculation, other irrelevant determinants include cooperation with the committee of social and legal protection of children $(\mathrm{M}=6.475 ; \mathrm{SD}=2.106)$; this falls within the category of intervention together with other Q-types - presence of a teacher with special qualifications in the school $(\mathrm{M}=6.576 ; \mathrm{SD}=2.429)$, cooperation with the school psychological advisory office $(\mathrm{M}=6.576$; $\mathrm{SD}=2.214)$ and presence of school psychologist in school $(\mathrm{M}=6.899$; $\mathrm{SD}=2.211$ ). On the other hand, the teacher's assistant, also included in the intervention category, was considered relevant, which (as we say above) is ascribed to their direct work with the pupils in the teaching process. The least relevant determinants in the eyes of the respondents also include existence of models of behaviour for the pupils to imitate $(\mathrm{M}=6.616 ; \mathrm{SD}=1.872)$ together with cooperative learning $(\mathrm{M}=6.495 ; \mathrm{SD}=2.192)$ and mental competence of the teacher $(\mathrm{M}=6.737$; $\mathrm{SD}=2.197)$.

Further least relevant determinants included inner differentiation of pupils at school $(\mathrm{M}=7.343 ; \mathrm{SD}=2.200)$ and unified school philosophy $(\mathrm{M}=7.212 ; \mathrm{SD}=1.991)$. We believe in the existence of a certain relation between perception of this determinant and support by the headmaster and peers, which was considered rather irrelevant. The low perceived relevance of these two Q-types might be connected with individual work with pupils (seen as very relevant), with the main aspect of trust between a given teacher and his/her pupils. Despite that, we believe that mutual support should exist between all teachers teaching socially disadvantaged pupils as well as a unified school approach, which may also be represented by inclusive education. The least relevant determinant category further included adjustment of class timetable $(\mathrm{M}=7.192 ; \mathrm{SD}=0.253)$ and material equipment of the classroom or school $(\mathrm{M}=7.364 ; \mathrm{SD}=2.252)$.

This is also connected with other determinants perceived by the respondents as the least relevant. The above is thus connected with adaptation of the environment $(\mathrm{M}=7.485$; $\mathrm{SD}=2.401)$ and other teaching arrangements $(\mathrm{M}=7.899 ; \mathrm{SD}=2.197)$. Also the low level of school inclusiveness is perceived as irrelevant $(\mathrm{M}=7.667 ; \mathrm{SD}=2.157)$.

The least relevant determinants as seen by our respondents was the social origin of the teacher $(\mathrm{M}=8.323 ; \mathrm{SD}=2.641)$ and the teacher's religion or race $(\mathrm{M}=9.303 ; \mathrm{SD}=2.341)$.

\section{Discussion}

Several research studies have been implemented on the issue of determinants of the educational process. They however mainly focus on socially excluded pupils, or socially excluded Romany pupils or pupils disadvantaged by the existence of their special learning needs (see Kaleja, 2014). Czech legislation, in particular Education act no 561/2004 Coll., include social disadvantage among special learning needs, which is connected with the implementation of support measures also for this group of pupils. Our study is thus based on the catalogue of support measures (Felcmanová and Habrová, 2015), focusing on the need for increased support to education of pupils with social disadvantages.

The respondents considered most relevant the reduction of the class number (Q-5). According to Felcmanová and Habrová (2015: 46), this measure consists in reduction of the number of pupils per teacher, and is a reaction to the refusal of the pupil to be engaged in the work in the classroom, insufficient homework of the pupil or high absence from school. This may be generally defined as reduced interest of the pupil in education. A little paradox may be that the determinant "pupil's interest in his/ her own education" (Q-38) was also assessed as very relevant. Also, the Framework Educational Plan 2013 (in Kaleja, 2015: 81) states that for successful education of pupils with social disadvantage certain conditions must be assured. One of them is also the reduced number of pupils in class. Kaleja (2015: 82) states, though, that there are also other aspects that must be taken into consideration, which are related to the educational situation of pupils with social disadvantages.

Mareš (1998, in Kaleja, 2015, p. 82-83) speaks about a strategy called "learn how to learn" and mentions that teaching styles may (but need not) be changed or affected. According to him, it is teachers who should most strongly influence the way the pupil will learn. This is also connected with the determinant defined as "modification of teaching methods" (Q-1). The catalogue of support measures (Felcmanová and Habrová, 2015) classifies it as support no. 2; i.e., modification of teaching forms and methods. The fundamental assumption for this measure is not only the profound knowledge of learning needs of every pupil but also the pupil's style of and motivation to learning. On the basis of our results, this determinant can be classified neither as relevant nor as irrelevant. This may be caused by its further subdivision to group learning (Q-14 - cooperative learning and Q-15 - group work supporting communication) and targeted creation of space/opportunities for pupils' self fulfilment (Q12). Although in professional literature these determinants are considered an important part of the teaching process, our respondents did not ascribe it any substantial relevance. This might be caused by the fact that conditions of work with pupils with social disadvantage are defined by the Framework Educational Plant, and for some teachers the conditions may be difficult to implement together. One of them is use of appropriate forms and methods, including cooperative learning, group work supporting the teaching process, as well as respect for individual work tempo and reduced resistance to stress (Kaleja, 2015: 82 ). And yet, the teachers are expected to adopt an individual approach to socially disadvantaged pupils (Q-23), as also follows from the catalogue of support measures (Felcmanová and Habrová, 2015: 77). This may be implemented by inner differentiation of class work, i.e. differentiation of the content as well as modification of the teaching methods. This, according to Felcmanová and Habrová (2015: 80), brings about risks such as the need for more extensive preparation of the teacher for lessons (Q-3), especially in the area of lesson planning and preparation of materials, and also the risk of too much freedom for the pupils in their decision-making about what to learn and how This is connected with the need for continuous cooperation and review. It is therefore understandable that these determinants are assessed as irrelevant in comparison to individual approach 
and individual work with the socially disadvantaged pupils despite the fact that "it is necessary to work with the class as a whole, without preference to any group or individual pupils." (Felcmanová and Habrová, 2015: 80). Maybe in connection with the necessity of individual work with the socially disadvantaged pupil, the presence of teacher's assistant is seen as very relevant (Q-8). The profession of this pedagogue is laid down in Section 20 of Act no 563/2004 Coll... On Pedagogical Profession, according to which the assistant "performs direct pedagogical activity in the class educating pupils with special learning needs or in school providing education to its pupils in the form of individual integration." The importance of this function in education of socially disadvantaged pupils is also shown by the Developmental Programme of the Ministry of Education, Youth and Sport of 2016 - "Support for funding teachers' assistants working with children, pupils and students with disadvantage." This programme concerns teachers' assistants working with pupils with physical handicaps or social disadvantages in the period of January to August 2016.

What is important in education of children and pupils with social disadvantages is a multidisciplinary approach; i.e., cooperation of the school and various experts, such as psychologists, special pedagogues or the committee for social and legal protection of children (Kaleja, 2015: 83). The presence of these experts was also mentioned by our respondents, in particular in the context of the category of social and health support. This measure exists in cooperation between the school and external service providers to pupils and families also for the prevention of undesirable social phenomena (Felcmanová and Habrová, 2015: 279). Support from the social and healthcare area serves not only teachers but also the school in general. As mentioned by Felcmanová and Habrová(2015: 279), the support also helps distribute efforts and support for the pupils and their families among more subjects, thereby forming a network of useful contacts of various experts, professional sites and specialised organisations. However well this works there are certain risks nevertheless. The greatest risk is the violation of personal data protection, or confidentiality, and also the late commencement of cooperation (Felcmanová and Habrová, 2015: 282). This is probably why these determinants in this category of measures (i.e., cooperation with the committee for social and legal protection of children, cooperation with pedagogical and psychological advisory service, presence of school psychologist at school etc.) are classified as insignificant.

Another interesting finding was made in the area of environment modification. According to the catalogue of support measures (Felcmanová and Habrová, 2015: 329-330), environment modification mainly involves the possibility for the pupil to retreat to a peaceful corner in the classroom where he/she can take a rest and calm down. The authors add that it may be part of the classroom or a separate room where the pupil is under supervision of the teacher alone, or teacher's assistant (which again points to the importance of this expert in the process of education of socially disadvantaged pupils). In the context of this measure, one can also speak about another spatial arrangement of the classroom (Q-10) or generally the environment (Q-4). For the application of this measure, there is another aspect and that is material equipment of the classroom (in the case of a separate corner within the classroom) or of the school as a whole (where we speak about a separate room for rest and relaxation) (Q-51). However, all these three determinants were assessed by our respondents as insignificant. On the basis of the results of our research, we can say that the respondents found as a suitable solution selection of an appropriate work place for the pupil, or overall rearrangement of the classroom seating plan (Q-11). This determinant is also mentioned in the catalogue of support measures (Felcmanová and Habrová,2015: 33) in which the authors refer to the importance of calming the pupil down, whether for the reason of a conflict or loss of concentration. An appropriate work place for the pupil is to be chosen not only in these cases but also in cases when the pupil works individually with the teacher or another pedagogue on other tasks. Although this determinant was classified neither as relevant nor as irrelevant, it helps acquire the important respect for the pupil's individuality (Q-21). It also partly helps motivate the socially disadvantaged pupils (Q-39) (by increasing their concentration to the performed activity and forming their learning and working habits), also helping maintain order and classroom atmosphere (Q-16) (the work with the socially disadvantaged pupil does not disturb activity of the rest of the class).

As we have already mentioned in the theoretical part of the study, in addition to the determinants springing from the support measures, there were also pupil-side and teacher-side determinants defined and analysed. On the pupil's side there were together five determinants defined: (Q-38), personality features of the socially disadvantaged pupil; (Q-41), the pupil's belief in his/her ability to influence the situation he/she is in; (Q-43), the pupil's healthy self-esteem;(Q-44) and educational aspirations of the socially disadvantaged pupils (Q-45). As mentioned by Rakoušová (2008), education and upbringing should be focused on development of the authentic personality of the pupil. This development is determined both by the pupil's personality features and by his/her self-esteem. Adequate selfesteem, according to the author, is always an upbringing tool. It forms positive features of the individual, at the same time contributing to regulation of the process of education and encouraging development of the pupil's personality. In the context of our research, the very personality features of the socially disadvantaged pupils were considered as more relevant than the remaining three determinants of this category. We can say that healthy self-esteem of the pupil further develops these personality features together with the pupil's belief in the possibility to influence the situation he/she is in. By means of self-esteem, the pupil seeks causes and derives consequences of his/her actions, analysing his/her own behaviour, proposing measures, learning about personal values, revealing his/her potential and accepting responsibility for his/her learning (Rakoušová, 2008). On the basis of the results of our research, we can conclude that the intended level of education of the socially disadvantaged pupil does not affect this any significantly.

According to Kohoutek (2010), the teacher is the main leader of the process of education and upbringing. Good governance must respect a number of factors, especially social and psychological aspects of upbringing, aspects of mental competence and stimulation of the pupil's activity. The very ability of the teacher to raise the interest of his/her pupils (Q-25) was classified by our respondents as very relevant. Another highly relevant factor is the pupil's individuality and respect for it (Q-21). According to Kohoutek (2010), the teacher is often required to address lack of concentration of the pupil, which may be caused by both short- and long-term factors. Kohoutek (2010) sees as a very negative factor the habit of non-concentration when the pupil does another activity, usually more interesting for him/her at the moment. This issue might be mitigated by consistent insisting of the teacher on educational requirements (Q-33), which 
was assessed as very relevant in our study. Kohoutek (2010), however, notes that very frequent requests for the pupils' concentration do not work, as the pupils get used to them and stop reacting to them. The teacher should also be consistent, but rather in the form of indirect stimuli, such as appropriate activation or request for expression of the pupils' own opinions. The teaching process must also respect the basic rules and standards of mental competence (Kohoutek, 2010). Mental competence was understood by our respondents as insignificant; it may be caused, for example, by the existence of breaks between lessons helping both the pupils and their teachers take a little rest and reduce fatigue. According to our respondents, a more important determinant was the teacher's resistance to stress (Q32). According to Hošek (2001), psychic resilience is defined by the level of (non)disruption of performance under stress. He further says that "the effort of trying to be perfect, diligent, considerate and helpful at any cost risks incurring a higher stress load than an indifferent individual". This is not to say that the teacher should be indifferent, but that he/she should consider his/her health and try to be as resilient as possible. We believe that for this very reason the relevance of resistance to stress prevails over the relevance of mental hygiene, which should be part of every profession but is not so relevant according to the respondents for people with increased psychic resilience.

The least important effect on education of socially disadvantaged pupils was seen by the respondents in the social environment the teacher came from (Q-24) together with his/her religious belief and $\operatorname{race}(\mathrm{Q}-30)$.

\section{Conclusion}

Although there are a number of research studies on determinants of the process of education, the present research may be considered solitary. The reason is its focus on socially disadvantaged pupils, defined by the current legislation within the category of "pupils with specific learning needs." In the context of the education act, which came to legal force on 1 September 2016, socially disadvantaged pupils are considered part of the class of pupils with special learning needs. This amendment incorporates into the act the notion of inclusive education, which then divides the current social opinion to two "camps" - for and against inclusion. Thus the respondents very often categorised the present research by the inclusion category. Another issue may be seen in the non-existence of a clear distinction between social exclusion and social disadvantage, which are still hard to tell apart. At the same time, the research was performed by the relatively uncommon Q methodology, allowing the respondents to sort the individual Q types by relevance with the possibility to change the answer at any later moment. Despite these obstacles, 99 filled-out questionnaires were returned, allowing us to sort all the 60 initially defined determinants of education of socially disadvantaged pupils in the order of their perceived relevance on the basis of the available theoretical basis, with the addition of a couple of interesting findings.

The most important of them is the very finding of the most relevant determinants affecting teachers in their educational work with socially disadvantaged pupils. They include both teacher-side determinants (i.e., the ability of empathy and understanding on the part of the teacher and the teacher's respect to the pupil's individuality) but also pupil-side determinants (such as the pupil's interest in his/her education). Another important determinant is one from the category of intervention (individual work with socially disadvantaged pupil) and from the category of environment modification (reduction of the number of pupils in class). Another principal finding is represented by the determinants considered by the respondents to be least relevant in relation to education of socially disadvantaged pupils. In their case, one can mention environment adaptation, where the respondents selected as the least relevant environment rearrangement together with spatial changes in the classroom. Another of the least relevant areas, according to the respondents, was teacher-side determinants: in particular religion, race and the social environment from which the teacher comes. The least relevant determinants also included the level of inclusiveness of the school, an issue currently much discussed.

On the basis of the above findings, it may be concluded that the area of education of socially disadvantaged pupils (whether addressed in the context of inclusive education by various support measures or not) must be viewed through the eyes of the teachers involved, astheir role in the whole process is crucial (Howes, Davis and Fox, 2009; compare Petr Šafránková, Hrbáčková, 2016b).

\section{Acknowledgements}

This article was supported by the Internal Grant Agency at Tomas Bata University under Grant The Determinants Influencing the Teachers' Educational Work in The Context of Education of Socially Disadvantaged Pupils on the Educational Level ISCED 1 and 2., number IGA / FHS / 2015/008.

\section{References}

Act no. 561/2004 from 24.09.2004 on Pre-school, Basic, Secondary, Tertiary Professional and Other Education (the Education Act) In: Collection of Laws of the Czech Republic, sum. 190.

Ainscow, M., Dyson A. and Booth, T. (2006) Improving schools, developing inclusion. New York: Routledge.

Artiles, A., Kozleski, J. and Waitoller, F. R. (2011) Inclusive education: examining equity on five continents. Cambridge, MA: Harvard Education Press.

Booth, T. and Ainscow, M. (2002) Index for Inclusion: developing learning and participation in schools. Centre for Studies on Inclusion Education, [Online], Available: http:// www.eenet.org.uk/resources/docs/Index\%20English.pdf $\quad[18$ Nov 2016]

Booth, T. and Ainscow, M. (1998) From them to us: an international study of inclusion in education. New York: Routledge.

Booth, T. (1996) A Perspective on Inclusion from England. Cambridge Journal of Education. 1996, Vol. 26, No. 1, pp. 8799. http://dx.doi.org/10.1080/0305764960260107

Bronfenbrenner, U. (1979) The ecology of human development: experiments by nature and design. Cambridge, MA: Harvard University Press.

Brown, S. R. (1996) 'Q Methodology and Qualitative Research', Qualitative Health Research, Vol. 6, No. 4, pp. 561-567. https:// doi.org/10.1177/104973239600600408

Buehl, M. and Beck, J. (2015) 'The Relationship between Teachers 'Beliefs and Teachers' Practices. In: Fives, Helenrose and Gill, Michele G. (eds.) International Handbook of Research on Teacher Beliefs. NY: Routledge, pp. 66-84.

Chráska, M. (2007) Metody pedagogického výzkumu: základy kvantitativního výzkumu. Praha: Grada.

Coogan, J. and Herrington, N. (2011) 'Q methodology: an overview', Research in secondary teacher education, Vol. 1, No. 2, pp 24-28. 
Čáp, J. and Mareš, J. (2007) Psychologie pro učitele. Praha: Portál.

Demeuse, M., Frandji, D., Greger, D. and Rochex, J. (2012) Educational policies and inequalities in Europe. New York, NY: Palgrave Macmillan.

Drake, S., Conchas, G., Hinga, B. and Gottfried M. (2015) 'Introduction', in Conchas, G., Gottfried M. and Hinga, B. (ed.) Inequality, power and school success: case studies on racial disparity and opportunity in education. New York: Routledge. Dyson, A. and Millward, A. (2000) Schools and special needs: issues of innovation and inclusion. Thousand Oaks, Calif.: Sage Publications.

Felcmanová, L. and Habrová, M. (2015) Katalog podpưrných opatřeni: dílči část: pro žáky s potrebou podpory ve vzdělávání $z$ důvodu sociálního znevýhodnění. Olomouc: Univerzita Palackého v Olomouci.

Filová, H., Havel, J. and Kratochvílová, J. (2009) 'Kurikulární vymezení podpory učení sociálně znevýhodněných žáků ve školních vzdělávacích programech“,in Němec, K. and Vojtová, V. Vzdělávání žáků se sociálním znevýhodněním. Brno: Paido. Greger, D. (2006) 'Vzdělanostní nerovnosti v teoretické reflexi' in Matějů, P. and Straková, J. (2006) (Ne)Rovné šance na vzdělání: Vzdělanostní nerovnosti v České republice. Praha: Academia.

Greger, D. (2010) 'Nerovnosti ve vzdělávání - od konceptů k měření' in Matějů, P., Straková, J., Veselý, A. and Basl, J. (2010) Nerovnosti ve vzdělávání: od měřni $k$ řešení. Praha: Sociologické nakladatelství (SLON).

Hošek, V. (2001) Psychologie odolnosti, [Online], Available: http://psychoweb.cz/psychologie/psychologie-odolnosti--v-hosek--stres-uzkost-frustrace-odolnost/ [25 Nov 2016]

Howes, A., Fox, S. and Davies, S. (2009) Improving the context for inclusion: personalising teacher development through collaborative action research, London: Routledge, Taylor \& Francis Group.

Kaleja, M. (2015) (Ne)prripravený pedagog a žák z prostředí sociální exkluze. Opava: Slezská univerzita v Opavě, Fakulta veřejných politik.

Kaleja, M. (2014) Determinanty edukace sociálně vyloučených žáků z pohledu speciální pedagogiky. Ostrava: Ostravská univerzita v Ostravě.

Kohoutek, R. (2010) Psychologie v teorii a praxi: Psychologie vyučování a výchovy, [Online], Available: http://rudolfkohoutek. blog.cz/1002/psychologie-vyucovani-psychodidaktika [25 Nov 2016]

Kotásek, J. (2001) Národní program rozvoje vzdělávánív České republice: bílá kniha. Praha: Tauris.

Lupton, R. and Hempel-Jorgensen, A. (2012) 'The importance of teaching: pedagogical constraints and possibilities in workingclass schools', Journal of Education Policy, Vol. 27, No 5, pp. 601-620. http://dx.doi.org/10.1080/02680939.2012.710016

Machová, J. (2008) Biologie člověka pro učitele, Praha: Univerzita Karlova v Praze.

Mareš, P. and Sirovátka, T. (2008) Sociální vyloučení (exkluze) a sociální začlenování (inkluze) - koncepty, diskurz, agenda. Sociologický časopis/Czech Sociological Review, 2008, Vol. 44, No. 2, pp. 271-294.

Mayer, E. S. (2003) What is a "Disadvantaged Group?, [Online], Available: http://www.effectivecommunities.com/ pdfs/ECP_DisadvantagedGroup.pdf [14 Dec 2016]

McDermott, R., Edgar, B. and Scarloss, B. (2011) 'Conclusion: Global Norming' in Artiles, A., Kolezleski, E.B. and Waitoller, F.R. (2011) Inclusive education. Cambridge: Harvard Education Press.
Michalík, J., Baslerová, P. and Felcmanová, L. (2015) Podpůrná opatření ve vzdělávání. Praha: Člověk v tísni.

MŠMT (2014) Strategie vzdělávací politiky České republiky do roku 2020, [Online], Available: http://www.vzdelavani2020.cz/ [14 Dec 2016]

Němec, J. and Gulová, L. (2012) 'The Integration of Socially Disadvantaged Pupils in the Czech Republic: A Qualitative View on Quantitative Pphenomenon (Disadvantaged Pupils in the Czech Republic: A Qualitative View on Quantitative Phenomenon)', in Visser, J., Daniels, H. and Cole, T. Transforming Troubled Lives: Strategies and Interventions for Children with Social, Emotional and Behavioural Difficulties. International Perspectives on Inclusive Education, Bingley, United Kingdom: Emerald Group Publishing Limited, pp. 161173, http://dx.doi.org/10.1108/S1479-3636(2012)0000002013

OECD (1998) Vzdélání a sociální spravedlnost v zemích OECD. Praha: Učitelské noviny - Gnosis.

Petr Šafránková, A. and Hrbáčková, K. (2016a) 'Teachers' Beliefs About Socially Disadvantaged Pupils in the Czech Republic', Procedia - Social and Behavioral Sciences, Vol. 217, pp. 738-747. http://dx.doi.org/10.1016/j.sbspro.2016.02.136

Petr Šafránková, A. and Hrbáčková, K. (2016b) 'Teacher SelfEfficacy within the Context of Socially Disadvantaged Pupils' Education', Sociální pedagogika | Social Education, Vol. 4, No 2, pp. 19-37. http://dx.doi.org/10.7441/soced.2016.04.02.02

Rakoušová, A. (2008) Metodický portál RVP: Sebehodnocení žáků, [Online], Available: http://clanky.rvp.cz/clanek/c/zu/1965/ SEBEHODNOCENI-ZAKU.html/ [25 Nov 2016]

Rawls, J. (1971) A theory of justice. Cambridge, Mass.: Belknap Press of Harvard University Press.

Rombo, L. (2006) Teachers' Attitudes Towards Inclusive Education. DWU Research Journal, no. 5.

Sociofaktor, s.r.o. (2013) Sociodemografická analýza: mapy rozložení ohrožení dětí a rodin $v \check{C} R$, [Online], Available: http:// www.mpsv.cz/files/clanky/15675/SOCDEM_ANALYZA_ OHROZENE_DETI.pdf. [16 Nov 2016]

Šafránková, A. and Kocourková, V. (2013) Analysis of the Teachers' Attitudes and Needs in Relation to Socially Disadvantaged Pupils in the Czech Republic. PEDAGOGIKA. SK, vol. 4, no. 2, pp. $144-159$. 